\title{
REFUGEE STATUS IN JAPAN: CHANGE OF JUDICIAL PRACTICE IN THE DEMOCRATIC STATE
}

\author{
Osamu Arakaki*
}

\begin{abstract}
This article considers the practice of Japanese courts in determining appeals to administrative determinations of refugee status in the 1980s and 1990s. Contrasting Japanese practice with that of New Zealand, the author highlights how the approach taken by the Japanese courts was characterised by conservatism and unwillingness to consider international jurisprudence. The author discusses how Japanese judges have appeared unfamiliar with internationally-accepted concepts of refugee law, and also reveals that in the practice of the 1980s and 1990s attorneys were insufficiently knowledgeable about refugee law. The author concludes by discussing ways in which Japanese practice has evolved since 2000, and considers some possible reasons for this development.
\end{abstract}

\section{INTRODUCTION}

Amongst those states which can be categorised as democratic, there are varying shades of liberalism, and a variety of different power structures and machinery. Japan acceded to the 1951 Convention Relating to the Status of Refugees (the Convention) on 3 October $1981^{1}$ and to the 1967 Protocol Relating to the Status of Refugees (the Protocol) on 1 January $1982 .^{2}$ The processes and results of the implementation of the Convention and Protocol in Japan have been shaped by the nature of its own domestic system as a constitutional democracy. At the same time, external elements have also been influential.

* Associate Professor, Faculty of Law, Shigakukan University; Visiting Associate Professor, the Graduate School of Arts and Sciences at the University of Tokyo, Japan. The views expressed in this paper are the personal ones of the author. They do not reflect the views of any bodies with which the author has associated.

1 Convention Relating to the Status of Refugees (28 July 1951) 189 UNTS 137; Japan's accession record: Treaty No 21 of 1981 .

2 Protocol Relating to the Status of Refugees (31 January 1967) 606 UNTS 267; Japan's accession record: Treaty No 1 of 1982. 
This paper reviews Japanese judicial practice concerning determination of refugee status during the 1980s and 1990s. The practice is characterised by both the Japanese judiciary's isolation from internationalism and its conservatism. However, judicial practice has recently been the subject of some limited change. This paper identifies, as factors leading to this domestic change, transnational processes and the network of the epistemic community. In doing so, it demonstrates accords and discords that have arisen between administrative and judicial authorities in Japan when they deal with the issue of refugee status determination.

Japan formed a statutory basis for refugee protection in the Immigration Control and Refugee Recognition Act (Amendment of the Immigration Control Order 1951) (the Act) when it acceded to the Convention and Protocol. Article 1A(2) of the Convention defines a refugee as someone who:

... owing to well-founded fear of being persecuted for reasons of race, religion, nationality, membership

of a particular social group or political opinion, is outside the country of his nationality and is unable or,

owing to such fear, is unwilling to avail himself of the protection of that country ...

Under the Act, no modification or alteration of the Convention definition of refugee is intended. ${ }^{3}$ The Act stipulates who makes decisions on refugee status and the basic process of refugee status determination. It introduces a two-tier system at the administrative level. According to the Act, both at the initial and appeal stages, decisions are made under the name of the same person, the Minister of Justice. Although the appeal process was modified by an amendment of the Act in $2005,{ }^{4}$ the basic framework of the system of refugee status determination has not changed since the Act first came into force. Decisions regarding refugee status made by the Minister of Justice may be appealed to the District Court and then to the High Court and the Supreme Court, the highest judicial institution in Japan.

\section{PRACTICE DURING THE 1980S AND THE 1990S}

In this section, aspects of Japan's judicial performance in determining refugee status during the 1980s and 1990s are looked at, with comparative perspectives from New Zealand's experience. The practice of New Zealand is characterised by internationalism. Insights deduced from New Zealand's experiences may be an effective means of seeking and highlighting aspects of Japan's performance in determining refugee status.

Immigration Control and Refugee Recognition Act, art 2-3-2.

4 The amendment of the Act was approved by the Diet in May 2004 and implemented one year later. In accordance with the amended Act, legal and international affairs experts are now involved in the procedure as Refugee Adjudication Counselors. The Minister must hear the views of the Counselors when making her/his decisions at the review stage. Despite the involvement of the Refugee Adjudication Counselors, the final authority for determination at the administrative stage is still with the Minister of Justice. 
For reasons of space, this section is limited to the issues of proving a "well-founded fear" and interpretations of "being persecuted".

\section{A Well-Founded Fear}

\section{Standard of proof}

This part discusses the degree of proof which may be understood to be required by the expression "well-founded", and what standard Japan applied in its practice during the 1980s and 1990s.

New Zealand applies the "real chance" test developed by the High Court of Australia, ${ }^{5}$ a more lenient alternative to the balance of probabilities standard of civil cases. ${ }^{6}$ According to the test, it is unnecessary for a refugee applicant to prove a 50 per cent chance of being persecuted. It is understood that unless persecution is a "remote chance", "far-fetched possibility", or "mere possibility", the required standard may be met. $^{7}$

This practice is necessary because these determinations entail a predictive appraisal of future events. While the test of balance of probabilities is useful when there is a legally relevant relationship between past causes and past effects, it is not appropriate when one prophesies the future. ${ }^{8}$ Furthermore, the interests with which the Convention is concerned comprise fundamental human rights including absolute ones. An error in the evaluation of a refugee application could result in prolonged detention, torture or even death for the applicant.

Japanese refugee cases from the 1980s and 1990s showed no recognition that the standard of proof to be applied was even an issue. Thus, there was no serious analysis or scrutiny of the issue to give guidance as to the appropriate standard. However, the following decisions provide some clues. In the case of AAKM $v$ Ministry of Justice, the Tokyo District Court employed the standard of an "ordinarily prudent person": 9

...in order to qualify as a person who has a "well-founded fear of being persecuted", it is necessary that there should exist, not only the subjective situation that the person concerned has fear of the danger of

5 Chan v Minister for Immigration and Ethnic Affairs [1989] 169 CLR 379, 407 (HCA) Toohey J; see, for example, Refugee Appeal No 74655 (12 November 2003) Refugee Status Appeals Authority 74655/03.

6 For instance, $\operatorname{Re} S$ (17 March 1995) Refugee Status Appeals Authority 523/92.

7 Chan v Minister for Immigration and Ethnic Affairs, above n 5, 407 and 429; ibid, 23-26. International Association of Refugee Law Judges "1998 IARLJ Pre-Conference Workshop for New Refugee Law Judges" (Documents prepared for the Pre-Conference Workshop, Ottawa, October 1998) Appendix B.

8 Guy S Goodwin-Gill The Refugee in International Law (2 ed, Clarendon Press, Oxford, 1996) 35.

9 AAKM and Three Others v Minister of Justice [1989] 40:7 Gyosai Shu (Collection of Administrative Cases) 913, 920 (DC); (1991) 34 JAIL 146 
being persecuted, but also the objective situation that an ordinarily prudent person might have fear of being persecuted, if she/he is placed in the position of the person concerned.

Interestingly, the formulation adopted by the Court is similar to that of the United States Ninth Circuit Court of Appeals which has suggested the standard of a reasonable person: that is, the enquiry is whether a reasonable person, if placed in the position of the person concerned, would fear persecution. ${ }^{10}$ However, unlike in the United States, the theory behind using the standard of the ordinarily prudent person was not explained in this case.

A Nagoya District Court decision, which was upheld by both the High Court and the Supreme Court, interpreted well-founded fear as that caused by both subjective and "imminent" situations. ${ }^{11}$ Similarly, a decision by the Tokyo High Court required the presence of "objective and concrete fear". ${ }^{12}$ These decisions have not expounded directly, however, on what "imminent situation", or "objective and concrete fear" imply with respect to the standard of proof. In other words, the degree of proof that the refugee applicant should achieve was not considered in relation to the phrases used.

It is worth reviewing how the standard of proof was dealt with in STA v Minister of Justice. ${ }^{13}$ The case was the only one in Japan during the 1980s and the 1990s in which a plaintiff applicant successfully had a refusal to recognise refugee status overturned. In the case, the applicant claimed refugee status on the grounds that legal proceedings had been brought against him in his home state, Pakistan, due to his religion. The defendant administrative authority submitted that there was a possibility the applicant would be acquitted. The Court responded that "Yet, the plantiff's having such responsibility does not mean that he is not qualified as a refugee." 14 Rejecting the administrative authority's presumption that the applicant would be acquitted, the Court stated further: $:^{15}$

...there is no evidence to acknowledge that the plaintiff's possibility of actually being punished has disappeared, as long as he is being prosecuted, and there is no way to avoid concluding that the plaintiff's fear of being persecuted continues now.

10 Guevara Flores $v$ INS (1986) 786 F 2d 1242, 1249 ( $5^{\text {th }}$ Cir).

11 SMA and Three Others v Minister of Justice (31 January 1994) GYO (U) No 35 of 1990, 36 (Nagoya District Court).

12 HAR and Another v Minister of Justice (26 March 1990) GYO (KO) Nos 78, 79 of 1989 (Tokyo High Court)

13 STA v Minister of Justice (29 October 1997) GYO (U) No 5 of 1997 (Nagoya District Court).

14 Ibid, 23.

15 Ibid, 24 . 
This refers to the probability that persecutory action was occurring while the determination was being made. In addition, the cited paragraph occurs in the context of the discussion of the phrase "well-founded fear of being persecuted" from the Convention.

In light of both the plain meaning of the sentences and the structure of the decision, a natural reading could be that it touches upon the standard of proof. The literal meaning of "disappearance of possibility" sounds tantamount to standards such as "reasonable possibility" and "real chance" or even something more lenient. As the wording of the criterion of the standard of proof is dissimilar to that of previous decisions, the terms used in the decision could be significant. On the other hand, given the lack of substantial discussion in the short decision, it is possible that the Nagoya District Court in this case did not deliberately adopt this more lenient standard based on legal theory. It can probably be assumed that this was the case and that the Court did not aim to build a framework for the standard of proof by identifying appropriate theories and reasons.

Refugee case law in New Zealand requires a consideration of future fear. ${ }^{16}$ By contrast, the forward-looking nature of the determination has not been appropriately analysed in Japanese practice. Only one decision explicitly used the term "future" when it considered the element of the applicant's fear of persecution. ${ }^{17}$ Contradictorily, several judicial cases seemingly required past persecution as a criterion for the recognition of well-founded fear.

The references to standard of proof in the Japanese courts during the period under consideration showed disunity, and the development of the legal theory behind the standard of proof is unclear. The overall tone of Japanese refugee decisions, however, was generally demanding with respect to the standard of proof. An applicant would be required to show "objective and concrete fear"18 to the extent that: 19

...there must be an imminent situation, for instance, that [the applicant] is actually being prosecuted ...or there is fear that [she/he] may be prosecuted in the future because an arrest warrant against her/him has already been issued.

It seems that this standard of proof is similar to that of civil cases. There is thus a possibility that the standard of proof used in normal domestic cases was substantially, and probably unconsciously, applied to the evaluation of refugee status without appropriate consideration and modification.

16 See, for example, Refugee Appeal No 72558/2001 (19 November 2002) Refugee Status Appeals Authority $72558 / 01$

17 SMA and Three Others v Minister of Justice above n 11, 36

18 HAR and Another v Minister of Justice, above n 12, 76.

19 SMA and Three Others v Minister of Justice, above n 11, 36. 


\section{Persons similarly situated}

Where an applicant does not claim past persecution, the circumstances of persons similarly situated in the state of origin are effective indicators in reasonably foretelling the future. Such persons include the applicant's family, relatives, friends, members or fellows of political or social institutions to which the applicant belongs, people who share the same religion, ethnicity and political view as the applicant and so on. The judicial and determination authorities in asylum states such as New Zealand often make use of this indicator in order to consider whether there is a well-founded fear in individual cases. ${ }^{20}$

The test of circumstances of persons similarly situated appeared in MAB v Minister of Justice: ${ }^{21}$

...it is verified that a brother and a cousin of the plaintiff were arrested and prosecuted. However, no evidence sufficiently corroborates the objective situation that the arrest and prosecution of the brother and cousin produce fear for the plaintiff of being arrested and prosecuted (For example, if the situation that the plaintiff was involved in were the fact which caused the arrest and prosecution of the relatives, [it would support the plaintiff's fear of arrest and prosecution]). Therefore, the arrest and prosecution of the plaintiff's brother and cousin do not directly validate the existence of the objective situation that the plaintiff would be in fear of being persecuted.

This decision saw only a formal linkage in terms of criminal procedure between the punishment exercised against the relatives and the actions of the applicant, and focused on assessing whether or not the punishment might be extended to the applicant. However, the indicator of similarly situated persons does not require an applicant to prove that a penalty will be imposed upon the applicant as a direct legal consequence of the association. Considering connections in terms of criminal procedure is not the only matter that can be drawn from the analysis of similarly situated persons. There was no discussion in the decision of the risk that an applicant could face forms of persecution other than prosecution.

In the evaluation of the risk facing an applicant, the Court in STA v Minister of Justice accepted the relevance of the situation of persons with similar situations as an additional indicator: ${ }^{22}$

The main issues [in dispute in the present case] ... are ... whether the plaintiff is qualified as a refugee, considering his situation and that of his relatives, given that he himself was not prosecuted nor faced the possibility of being punished.

$20 \operatorname{Re} \operatorname{MSM}$ (1 March 1994) Refugee Status Appeals Authority 300/92.

21 MAB v Minister of Justice (30 August 1996) GYO (U) No 4 of 1995, 41 (Nagoya District Court).

22 STA v Minister of Justice, above n 13, 5. 
While recognising the value of the indicator, it was unnecessary for the Nagoya District Court to consider the position of persons similarly situated, given it was satisfied that the applicant was a refugee on the basis of evidence concerning the individual's circumstances alone. ${ }^{23}$

\section{B Persecution}

The previous part threw light on evidential issues in Japanese practice. This part explains the interpretation of the term "being persecuted".

\section{Basic standards and concepts}

It is only recently that the term "persecution" was codified in international instruments. Whilst various interpretations of persecution have been attempted when applying international instruments, the term is not clearly defined in the instruments and its definition cannot be ascertained from the drafting process.

Similarly, the Convention does not articulate what "being persecuted" means. The Convention itself is silent as to what kinds of harm constitute being persecuted, how serious harm must be, who the persecutors can be and so on. However, this has not precluded state parties to the Convention and the academic community from attempting to articulate the scope of the term. For instance, some asylum states have set objective standards in order to determine if the claimed harm is persecution. New Zealand approves James Hathaway's definition, ${ }^{24}$ that is, "the sustained or systemic violation of basic human rights demonstrative of a failure of state protection." 25 It then refers to international human rights treaties to examine whether the threat of harm to a person or interference with her/his rights constitutes "being persecuted". ${ }^{26}$ In this context, the Universal Declaration of Human Rights, the International Covenant on Civil and Political Rights and the International Covenant on Economic, Social and Cultural Rights are pertinent. New Zealand has continued to develop its interpretation of being persecuted since adopting this human rights-based approach.

Japan has acceded to various human rights treaties, and a characteristic of the Constitution of Japan is its emphasis on international cooperation. Yet Japan's judiciary has neither incorporated nor utilised standards driven by international human rights law to measure what harm amounts to persecution in terms of the Convention.

23 Ibid, $22-24$.

24 Re MN (12 February 1996) Refugee Status Appeals Authority 2039/93; Refugee Appeal No 74655/03 above n 5 .

25 James C Hathaway The Law of Refugee Status (Butterworths, Toronto, 1991) 104-105.

26 Refugee Appeal No 71427/99 (16 August 2000) Refugee Status Appeals Authority 71427/99. 
In AAKM v Minister of Justice, the Tokyo High Court defined the term persecution in a conclusive way: ${ }^{27}$

... it is proper to understand its meaning as an assault or pressure which causes an ordinary prudent person unbearable pain, and as an infringement or oppression of life or physical freedom.

This and similar passages from $A A K M$ were followed in many later judicial decisions. ${ }^{28}$

Yet in OFE v Osaka Immigration Control Office, Chief Inspector, the Osaka High Court employed different terminology, articulating persecution in terms of an infringement of human rights, as follows: ${ }^{29}$

... it is understood that persecution means a threat to life or physical freedom, or serious infringement against human rights to a degree which makes it impossible for a person to return to or to stay in the state of origin.

However, nowhere in the decision is there any guidance as to what the expression "serious infringement against human rights" implies.

\section{Agent of persecution}

The position taken in New Zealand is that persecution demands neither state commission nor complicity. ${ }^{30}$ Given that the absence of protection means that the state is failing to fulfil its duty to defend the interests of its citizenry or protect citizens' basic needs, the involvement by state organs in the projection or action of persecution is not a precondition to the recognition of persecution. ${ }^{31}$

The Nagoya District Court in SMA v Minister of Justice took a different position: ${ }^{32}$

... the plaintiff claims that his business did not go well because of his being an Ahmadi and that he was required to vacate the store he rented [for the same reason]. However, providing the claims are true, both are actions of customers or the landlord of the store. It is obvious that the government authorities are not involved in the actions.

27 AAKM and Three Others $v$ Minister of Justice, above n 9, 922.

28 See, for instance, $A G$ and Three Others $v$ Tokyo Immigration Control Office, Chief Inspector (29 September 1997) GYO (U) No 219 of 1995 (Tokyo District Court) 71-2.

29 OFE [1994]46:2 Koto Saibansho Keiji Hanreishuu (Collection of High Court Criminal Cases) 204, 218 (HC).

30 For instance, see $\operatorname{Re} M N$, above n 24.

31 Refugee Appeal No 11/91 Re S (5 September 1991) Refugee Status Appeals Authority 11/91.

32 SMA and Three Others $v$ Minister of Justice, above n 11, 41. 
The decision implicitly suggested that an action committed by a state authority was a prerequisite to the recognition of persecution.

Almost two and half years later, the same Court applied a slightly more liberal interpretation in MAB v Minister of Justice: ${ }^{33}$

... [To satisfy] the condition of 'well-founded fear of being persecuted' (of article 1 of the Convention), actions taken by state authorities must be involved. If a fear of being attacked on account of religion by individuals of one part of the people exists, it cannot be said immediately that the said condition exists.

Reasonably, there is room for explanation that the said condition may exist if the state authorities condone attacks by individuals of one part of the people or refuse to provide victims with appropriate protection. However, ... [in the present case,] there is no precise evidence to the effect that the state authorities condone [the claimed attacks] in general or refuse to provide the victims with appropriate protection ...

Yet, as the decision required applicants to provide proof of the ill intent of state authorities, it effectively maintained the understanding that the inability of the state to provide protection is not sufficient. The decision did not explain why this interpretation should be taken.

\section{ISOLATION FROM INTERNATIONAL PERSPECTIVES}

Many state parties rely not only on domestic but also international legal sources to interpret the definition of refugee in the Convention. The sources which are frequently used by state parties are records of the Convention's negotiation history, the views of academic commentators and materials of the United Nations High Commissioner for Refugees (UNHCR). This tendency is a natural consequence of the premise that the definition of refugee is supposed to be drawn from international agreement and not from a state party's own interpretation.

In contrast, during the 1980s and 1990s, Japan kept its distance from the broad international view and the practice of other states and international organisations when interpreting the term "refugee".

None of the refugee decisions in Japan seriously considered international legal sources. The Tokyo District Court commented in HAUI v Takamatsu Immigration Control Office, Chief Inspector on the evidential value of the UNHCR's Conclusions on the International Protection of Refugees

33 MAB v Minister of Justice, above n 21, 38-39. 
adopted by the Executive Committee of the UNHCR Programme (EXCOM Conclusions) ${ }^{34}$ as follows: ${ }^{35}$

However, ... the Conclusions of the UNHCR's Executive Committee do not legally bind the State Parties to the Refugee Convention and the Protocol. Moreover, the members of the Executive Committee [including Japan] do not have a legal obligation to observe the contents of the Conclusions of the Executive Committee ...

It may be correct to say that the EXCOM Conclusions in general do not legally bind Japan and the Committee members automatically. However, the EXCOM Conclusions may contain persuasive logic and rationale on which courts may rely. Moreover, the dynamics of the interaction between any one conclusion of the EXCOM Conclusions and state practice, and the value of the conclusion as a means to interpret the Convention should be examined. That is to say, evaluation of the evidential value of a specific EXCOM conclusion requires investigation of its normative nature. For instance, to what degree did existing state practices influence the development of the specific resolution? Has the conclusion been incorporated in the subsequent practice of the state parties to the Convention? Has the conclusion been firmly observed by the state parties? If so, is it possible to assume that the particular EXCOM conclusion represents particular rules and standards of a binding nature, or reflects international custom, and that the various state parties identify various elements of the Conclusions with which states must comply? The conclusion could have an evidential value in the application of the Convention in state practice.

The Japanese courts also declined to use other resources which may help interpret the terms of the Convention. The decision of RQT v Minister of Justice ${ }^{36}$ of the Tokyo High Court denied the necessity of knowledge of the Handbook on Procedures and Criteria for Determining Refugee Status Under the 1951 Convention and the 1967 Protocol Relating to the Status of Refugees (UNHCR Handbook). ${ }^{37}$ The applicant claimed that the UNHCR Handbook should be consulted under article 32 of the Vienna Convention on the Law of Treaties as a "supplementary means" to interpret the term refugee and to figure out the appropriate standard of proof for determining refugee status. The Court rejected the argument on the grounds that the UNHCR Handbook was not a "supplementary means" in terms of the Vienna Convention on the Law of Treaties. The Court's decision also implied the

34 Office of the United Nations High Commissioner for Refugees Conclusions on the International Protection of Refugees adopted by the Executive Committee of the UNHCR Programme (Office of the United Nations High Commissioner for Refugees, Geneva, 1990).

35 HAUIv Takamatsu Immigration Control Office, Chief Inspector (10 March 1999) GYO (U) No 162 of 1996 , 56 (Tokyo District Court).

36 RQT v Minister of Justice (26 June 2000) GYO (KO) No 103 of 1999 (Tokyo High Court).

37 Office of the United Nations High Commissioner for Refugees Handbook on Procedures and Criteria for Determining Refugee Status Under the 1951 Convention and the 1967 Protocol Relating to the Status of Refugees (Office of the United Nations High Commissioner for Refugees, Geneva, 1979). 
needlessness of any supplementary means, including the survey of the Convention history, when interpreting the definition of refugee: ${ }^{38}$

...concerning the term 'refugee' which is stipulated in article 1 of the Refugee Convention and in article 1

of the Refugee Protocol, as it can be interpreted without using supplementary means [provided in the

Vienna Convention]..., it should be said that it is not necessary to confirm the interpretation by resorting

to supplementary means.

\section{JUDICIAL CONSERVATISM}

Another feature of Japan's refugee status determination practice may be described as judicial conservatism. This feature relates to, and even exacerbates, the effects of the above-mentioned isolation from international perspectives.

Only once did the courts choose to reverse a refusal to recognise refugee status during the $1980 \mathrm{~s}$ and 1990s. ${ }^{39}$ Japanese courts were inclined to almost automatically uphold the fact finding and legal interpretations of the administrative authorities in refugee cases. The overall tone of refugee decisions during this period encouraged the suspicion that the administrative decisions of the Minister of Justice in refugee cases were accepted unquestioningly by the judiciary, and that independent examination by the judicial arm had been renounced. Rather than the judiciary working as the final fortress for human rights, the passive attitude of the courts contributed to an accord between judicial and administrative actions in determining refugee status. The conservative position chosen by the Japanese courts during these decades served to maintain harmony with the administrative arm at a cost to the human dignity of the refugee applicants.

\section{A Judicial Restraint}

The almost universally negative conclusions in refugee cases in Japan during these decades appear to be the result of the restraint which was generally exercised by the conservative Japanese courts. In more than 80 per cent of all cases the Japanese government's administrative actions have been upheld against challenge. ${ }^{40}$ Given the one-sided results, it is widely agreed that the courts, particularly the Supreme Court, were reluctant to review administrative actions. Especially when the cases involved significant political issues, "there is little doubt that the courts - or at least the Supreme Court - have themselves been reluctant to deal with challenged governmental actions on the merits". 41 This judicial restraint echoed profoundly in the realm of refugee decisions.

38 RQT v Minister of Justice, above n 36, part 3, para 2.

39 STA v Ministers of Justice, above n 13.

40 "Statistics on Administrative Litigation: Research Conducted by the General Secretariat of the Supreme Court" www.kantei.go.jp (accessed 28 May 2007).

41 John O Haley "Japanese Administrative Law" in Kenneth L Port (ed) Comparative Law: Law and the Legal Process in Japan (Carolina Academic Press, North Carolina, 1996) 635, 645. 
The reluctance to get involved may have stemmed from a wish for harmony with government or may have been a product of the desire to avoid tensions that could jeopardise the status and prestige of the judiciary. Formally, judicial autonomy is secured by the Constitution, ${ }^{42}$ but the reality has been much more complicated. Japanese judicial conservatism originated in the history of power conflict between the executive and judicial arms of the state which began in the 1950s. Pressured by a conservative political faction, the Japanese judiciary was determined to demonstrate restraint in order to avoid external interference.

\section{B Judges}

The quality of the decisions in refugee cases reflected the simple fact that judges lacked experience with the subject matter. By 1999, only 48 court proceedings relating to refugee status were recorded. The lack of experience deprived the judges of the opportunity to evolve their legal consciousness in examining refugee cases and adapt appropriate legal rules and techniques from other state parties. For Japanese refugee law judges, the chance to think seriously and comparatively about the compatibility, adaptability and universality of refugee law was also limited.

The deficiency in the training and experience of judges in international human rights law is also relevant to the quality of decisions. Attorneys in human rights cases have complained of the lack of understanding by Japanese judges of international human rights law. Japanese judges are inadequately trained in international law, and even less so in international human rights law. To avoid awkwardness in an area with which they are unfamiliar, courts sometimes utilise interpretations from municipal law and apply domestic standards, principles and reasoning to a comparable situation in international human rights cases. Consequently, the courts tend to dismiss arguments based on international human rights law without detailed analysis of their substance. ${ }^{43}$

Refugee law was not immune from this tendency. Without any question or analysis, for instance, Japanese courts seemingly assumed that the legal onus and standard of proof in refugee determination was the same as that of domestic Japanese law, in spite of the differing nature of refugee law. The lack of knowledge or awareness of the unique principles of credibility assessment in refugee cases also had its roots in this tendency.

\section{Attorneys}

Compared with judges, the professional performance of bengoshi (attorneys) has not been the subject of much discussion. More enthusiastic and professional participation by attorneys in the refugee status determination process would have had a decisive impact on results. In the past, refugee law attorneys claimed that they did not place confidence in judicial appeals since the courts were

42 Constitution of Japan, arts 76-3.

43 Yuji Iwasawa International Law, Human Rights, and Japanese Law: The Impact of International Law on Japanese Law (Clarendon Press, Oxford, 1998) 292, 294 and 303. 
extremely reticent to substantively review decisions made by the Minister of Justice. However, it was also probable that the attorneys themselves were not confident enough in their own skills and knowledge of refugee law to challenge the decisions made by the Minister of Justice. Thus refugee law attorneys were partially responsible for the lack of judicial exposure to refugee cases in Japan. Until recently, few attorneys had seriously attempted to make substantive arguments about proof of refugee status and the definition of refugee in the courts.

The short supply of attorneys in Japan is well documented, although reform to increase the number is underway. Given the relatively small number of refugee applications in Japan, the number of qualified lawyers who were involved with assisting refugee applications was not disproportionately small. The problem was rather the quality of their work. As far as their assistance to refugee applicants was concerned, the performance of the legal profession in general was rarely professional. For example, in one case, the interview records and supporting documents prepared by the applicant's attorney demonstrated a lack of knowledge of refugee law, and lack of comprehension and accuracy in compiling the refugee claim. The applicant's refugee status was denied by the Minister of Justice on the grounds of credibility problems and the lack of a well-founded fear of persecution. The attorney did a disservice to the case of the applicant because the statements setting out the refugee claim were prepared and submitted without expertise in refugee law and due attentiveness. Similarly, attorneys' lack of skills in assembling external and corroborative evidence was a problem. In the past, refugee law attorneys rarely even attempted to access reliable human rights information about clients' states of origin from recognised sources. Furthermore, the Japanese courts' cliquish characteristic of being reluctant to consider foreign refugee case law was attributable, in part, to refugee law attorneys. The attorneys did not attempt to promote the interpretations and doctrines of the Convention as confirmed by other state parties as a legal source in the Japanese jurisdiction.

However, the problems were partially caused by obstacles that the attorneys could not control or did not recognise. Firstly, the lack of legal aid allocated to refugee applicants discouraged refugee law attorneys from representing refugee applicants with adequate care and commitment. Due to the dearth of financial resources, the translators or interpreters relied on were more often than not insufficiently skilled. People from the community helped voluntarily. Worse still, it was not unusual that a common language such as English, which was the mother tongue for neither the applicant nor the attorney, was used during interviews to obtain the applicant's account. Despite the fact that preparation needed considerable time, the financial situation of the clients and the lack of profit made refugee cases a low priority and deterred attorneys from spending sufficient time assisting applicants set out their claim and collecting relevant evidence.

Just like the judges, the attorneys in the field of Japanese refugee law were not well-informed or trained in this branch of the law. Hence, they were inclined to stick to conventional ideas from domestic law with which they were confident. A prominent refugee attorney stated that he was inclined to consider the credibility of refugee applicants according to the standard of domestic law. 
Another attorney admitted that it was difficult for her to "feel reality" in her client's claim, and one of the reasons was that she was shackled by the "yardstick of Japanese society". Like judges, it was hard for the attorneys to understand the systems which produced victims of persecution.

In addition, linguistic barriers have hindered attorneys' chances of systematically learning doctrines and skills developed in international refugee law. It has been suspected, as a result of dialogue with the refugee law attorneys, that few of them had read even one essential textbook. Some attorneys did not even know the names of the prominent scholars in the area. The absence of academic Japanese language materials guiding refugee law further hindered the development of attorneys' knowledge.

In the broad political process, academics in Japan have the power to influence public affairs in all phases of the public decision-making process. They have influence through their teaching, their books and articles, which form the basic parameters of public discussion, and the mass media. The scantiness of intellectual input in Japan caused a lack of instruction to pilot Japanese refugee law attorneys into stimulated and advanced legal argument. Except for involvement by a few scholars who wrote on the interpretation of refugee status, the growth of the academic community involved in refugee law was minimal in the 1980s and 1990s. There were no Japanese translations of basic textbooks. Moreover, unlike law schools in New Zealand and other states, no academic institutions in Japan offered core courses on refugee law. The absence of such courses hindered the fostering of young jurists with expertise in the philosophy, wisdom and determination - including the skills of interpretation and application - of the law.

\section{DOMESTIC CHANGE: CREDIBILITY ASSESSMENT}

The previous sections have described a judicial environment in which Japan disengaged from the international stage and held fast to its conservative practice in determining refugee status. However, in contrast to the past, the number of refugee decisions overturned by the courts has increased since the beginning of the new millennium. According to the author's knowledge, more than 30 administrative decisions rejecting refugee status from among approximately 200 judicial appeals have been overturned, mainly by the district courts, between the beginning of 2001 and October of 2006. At the same time as this quantitative change, the quality of judicial decisions on refugee cases has also improved to some extent. Although progress in interpreting the elements of the refugee definition has not been huge, recent court decisions are much more careful with respect to credibility assessments. It is intriguing that the recent development with respect to credibility assessment accords with international practice. The cases discussed in the following parts are not comprehensive but selective. 


\section{A Interrelation between Credible and Non-Credible Evidence}

New Zealand practice requires that decision-makers assess "well-foundedness" based only on "unpolluted facts". ${ }^{44}$ That is to say, the assessment should proceed on the portions of the claim which are accepted as true since lack of credibility in one piece of evidence does not suggest that all the evidence lacks credibility. ${ }^{45}$ A negative influence may prevail over other parts of evidence which logically derive from the doubted portions or which are concomitant to them, but any such negative conclusion should only be drawn after careful evaluation of the nature of the logical connection.

As an example of past practice, in $A A^{46}$ the Tokyo District Court examined the credibility of the defendant, a refugee applicant, with respect to exemptions for penalties for immigration offences under the Act. The Court refused to believe his testimony that he would face the risk of persecution upon his return to the state of origin, stating that: ${ }^{47}$

\footnotetext{
... regarding the parts [of the defendant's testimony] that he has been persecuted [in Japan] from the time just before his arrest [in the state] until today for instance in the circumstances that his bag was checked by the [Japanese] police officers without his permission on the day he was arrested and that while he was in detention [by the Japanese authority] he was maltreated, in reference to [the evidence], the content of his testimony is unnatural and lacks credibility ... when considered together with the circumstances [concerning other parts of evidence], ... it is difficult to say that the defendant has succeeded in proving that he belongs to a group in fear of persecution ...
}

The applicant's story about the incidents in Japan gives no basis to doubt the applicant's credibility on the aspect of well-founded fear of being persecuted in his home state because there is no logical link connecting the two parts of his claim.

However, a more recent court decision has dealt with the issue more carefully. In TRF v Nagoya Immigration Control Office, Chief Inspector, ${ }^{48}$ the Court found discrepancies between the English and Japanese translations of a letter which the applicant received from an acquaintance in his state of origin. The Court concluded that the applicant fabricated the Japanese translation by adding information that was not written in the original letter in order to enhance his claim. Notwithstanding,

44 See Roger PG Haines Seminar on Duties of Decision Maker and the Writing of Decisions (Internal seminar document, Refugee Status Appeals Authority, Wellington, September 1995) 15.

45 See, for instance, Hilo $v$ Canada (Minister of Employment and Immigration) (1991) Imm LR (2d) 199 (FCA).

46 Case of AA (4 February 1999) TOKU (WA) No 1090 of 1998 (Tokyo District Court).

47 Ibid, paras 3-8, 4-1.

48 TRF v Nagoya Immigration Control Office, Chief Inspector (16 May 2000) GYO (KU) No 7 of 2000 (Nagoya District Court). 
the Court separated the issues of the fabrication of the translation and the genuineness of the original letter, and accepted the credibility of the letter itself: ${ }^{49}$

[The fabricated contents of the Japanese translation] accord with information that the applicant heard on the telephone and with generally reported news. The identification of such portions [in the Japanese translation] does not however damage the credibility of the [original] letter itself.

\section{B Motivation for Departure}

In a refugee determination system whose functions are dominated by rules and the attitudes of immigration officers, the impression that a refugee must have a single emotion, namely fear, is prevalent. However, the existence of additional motivations for an applicant's departure, such as seeking a better life in terms of economic or immigration prospects, does not prove the absence of a well-founded fear of being persecuted. The duty of decision-makers is the objective evaluation of the risk that the applicant would be persecuted upon return, not the search for subjective human desires. Fear of persecution and other desires are not mutually exclusive, and can co-exist in a person's mind. Logic dictates that finding an intention to immigrate does not prove the claim for refugee status to be manifestly unfounded.

In OFE v Osaka Immigration Control Office, Chief Inspector, ${ }^{50}$ where the applicant's refugee status was in question, the Court overlooked the possibility of dual or multiple motivations for a refugee's departure: ${ }^{51}$

...since it is generally recognised that the appellant's motivation for illegal entry into Japan was the purpose of migrant labour in order to make money by working [in this state], it cannot be said at all that the appellant left China, his state of nationality, because of fear of persecution ...

The error in this statement is the assumption that economic motivation excludes a well-founded fear of being persecuted. The immediate motivation for a person's departure may be "making money", but there is a possibility of fear of being persecuted as well as the motivation of making money.

Even to this day, many court decisions raise economic motivation as a basis on which to doubt the credibility of the applicants. On the other hand, a more liberal understanding has appeared in some decisions. In 2002 the Hiroshima District Court, in the criminal case of RES v Japan (Prosecutor), ${ }^{52}$ concluded that the Afghan applicant should be granted refugee status and exempted

49 Ibid, 24-25.

50 OFE v Osaka Immigration Control Office, Chief Inspector (1994) 837 Hanrei Taimuzu (Case Law Times) 242 (DC).

51 Ibid, 244.

52 RES v Japan (Prosecutor) (20 June 2002) WA No 225 of 2002 (Hiroshima District Court). The Hiroshima High Court on 20 September 2002 upheld the part of the decision concerning the grant of refugee status. 
from penalty for violation of the Act. In assessing the credibility of the defendant, the Court accepted compatibility of fear of being persecuted with the motivation of labour: ${ }^{53}$

Even if the defendant (applicant) was motivated by the possibility of working in Japan at the same time, it does not preclude the acknowledgement of his will to seek asylum.

\section{TRANSNATIONAL PROCESSES AND THE NETWORK OF THE EPISTEMIC COMMUNITY}

The near perfect harmony between the administrative and judicial authorities witnessed during the 1980s and 1990s was abandoned in the early 2000s. It is difficult to comprehensively discuss the background of the recent changes in refugee law practice in Japan, which includes various elements. For the purposes of this paper, however, it is worth highlighting the transnational processes that, through the state's national democratic functions, have led to this change in approach. This section also considers the networks of the epistemic community for the transfer of knowledge and wisdom which have influenced changes in practice.

In democratic states, the actors that have the final authority to determine refugee status are state institutions, including judicial, quasi-judicial and administrative bodies. That is to say, refugee status determination is formally a role undertaken by the state. However, transnational processes influence these national functions. Non-state actors such as NGOs, advocacy groups and media are part of this process. In particular, attorneys have initiated the incorporation of the practices of other states into their strategy for succeeding in court. In respect of some aspects, the national judiciary has been persuaded by the rationality of the standards and principles identified in foreign jurisprudence. Consequently, the Japanese judiciary in refugee cases has gradually accepted international perspectives and to some extent abandoned its conservatism.

As part of this process, a loose network within Japan has emerged. The UNHCR Representation in Japan and academic scholars of refugee law play the role of mediators who transmit theory and philosophy accumulated in international practice to refugee law attorneys. NGOs working for refugee protection have organised seminars on refugee law, inviting UNHCR staff members and university professors. Lecture topics have varied from determination procedure, credibility assessment, onus of proof, and standard of proof to the Convention grounds.

Currently, practitioners are looking across borders to find intellectual sources for the cultivation and formulation of knowledge. There is a movement in Japan towards including itself in the international community of refugee law jurisprudence. Beginning with the appearance of three Japanese nationals in the International Association of Refugee Law Judges conference in 1998, the involvement has included the participation of a Tokyo High Court judge in the Bern Conference of that Association held in November 2000.

53 Ibid, section 2, para 4 . 
In addition to the above multilateral dimension, bilateral relationships are gradually appearing. In 2001, a foreign expert, Allan Mackey, the former Chairperson of the New Zealand Refugee Status Appeals Authority and the former President of the International Association of Refugee Law Judges, was invited to the Tokyo District Court as a witness to testify on issues including due process, assessment of credibility and the interpretation of the definition of refugee.

The information technology revolution offers to play a role in activating a chain reaction in refugee law beyond borders. In order to support their cases, refugee law attorneys in Japan now enjoy the benefits of many more sources of information. They often utilise information contained in web pages about the refugee law jurisprudence of New Zealand, Australia, Canada and other states.

\section{CONCLUSION}

This paper has considered past Japanese practice in determining refugee status, some features of that practice, recent change and its background. It should be noted, however, that it has focused on practice and change mainly in the judicial field. Various other factors in the legal, social, economic and political dimensions, which have not been covered in this paper, contributed to the formation and change of practice.

For instance, in the context of Japan's democratic functions, administrative approaches to determining refugee status were affected by the legislative process. After Japan acceded to the Convention and Protocol, when implementing the relevant legislation, the Diet noted the absence of a consistent and rigid interpretation of refugee accepted in international law. Despite this, the Diet did not fully consider the essence of the definition of refugee. The Diet failed to define "refugee" in a way that would assist refugee applicants and the courts. This inadequate examination of the nature of definitional terms during the legislative process has permitted excessive administrative license.

The Convention itself does not directly elaborate on the minimum standards for determination procedures or clarify the definition of refugee. Thus, in order to achieve absolute refugee protection, the key question is how serious the state parties are about filling the gaps in the Convention by incorporating the understandings and standards of international human rights law. The incorporation of the human rights vision into the implementation of the Convention and Protocol will be influenced not only by, for instance, concerns of national security, but also by the unique nature of the democratic functions of the various state parties as well as universal transnational processes. 